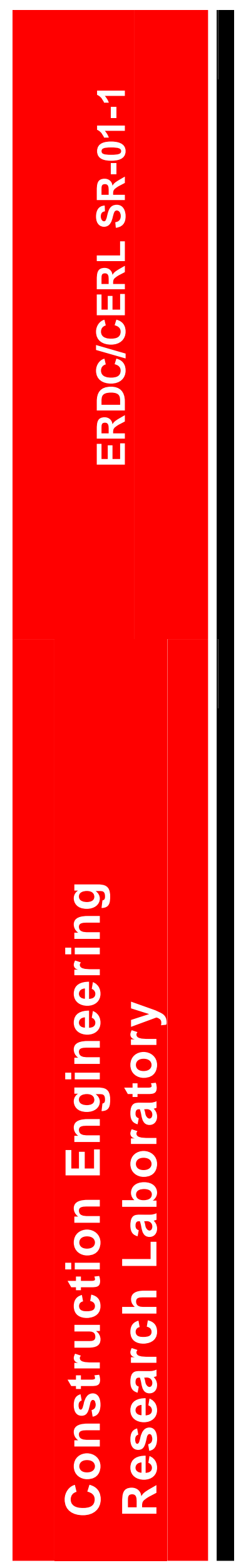

\title{
User Guide and Specifications for Baked Phenolic Coating Systems Applied to Domestic Hot Water Heat Exchangers
}

Vincent F. Hock January 2001 


\section{Foreword}

This study was conducted for the Center for Public Works (USACPW), which has more recently been reorganized into the Directorate of Military Programs, Headquarters, U.S. Army Corps of Engineers (HQUSACE), under the Facilities Engineering Application Program (FEAP). The technical monitor was Malcolm McLeod, CEMP-RI.

The work was performed by the Materials and Structures Branch (CF-M) of the Facilities Division (CF), Construction Engineering Research Laboratory (CERL). The CERL principal investigator was Vincent F. Hock. Martin J. Savoie is Chief, CEERD-CF-M, and L. Michael Golish is Chief, CEERD-CF. The Acting Technical Director of the Facility Acquisition and Revitalization business area is Dr. Paul A. Howdyshell. The Acting Director of CERL is William D. Goran. The CERL technical editor was William J. Wolfe, Technical Resources.

CERL is an element of the U.S. Army Engineer Research and Development Center (ERDC), U.S. Army Corps of Engineers. The Director of ERDC is Dr. James R. Houston and the Commander is COL James S. Weller. 


\section{Contents}

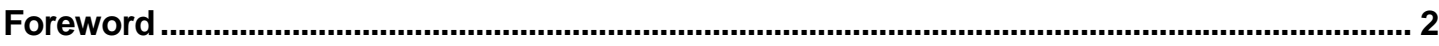

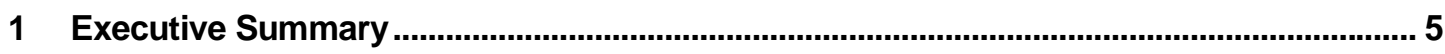

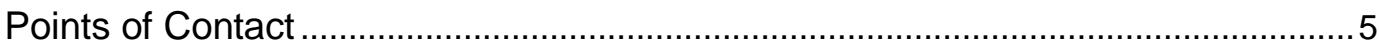

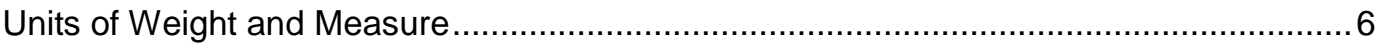

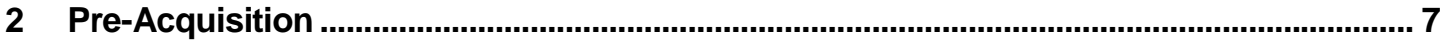

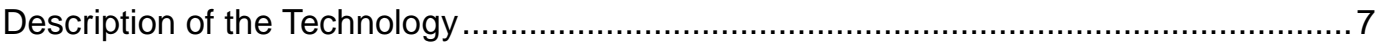

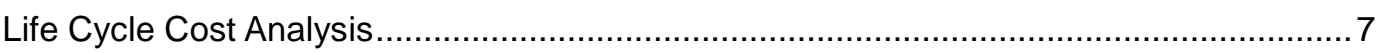

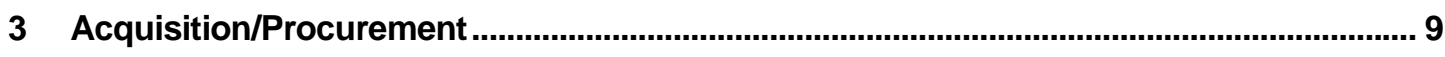

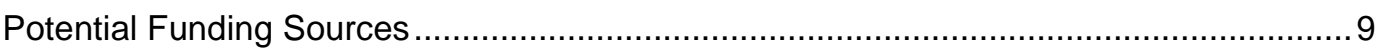

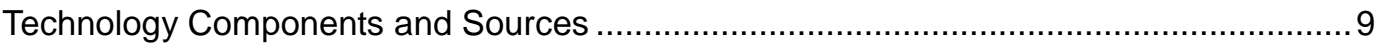

Procurement Documents ................................................................................

Corps of Engineers Guide Specification Section 15400 Plumbing, General Purpose...... 10

Corps of Engineers Guide Specification Section 15405 Plumbing, Hospital .................... 11

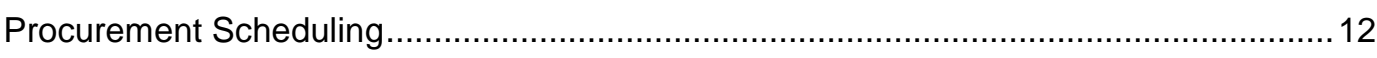

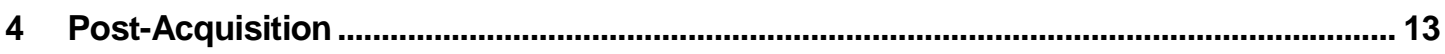

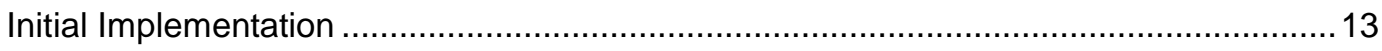

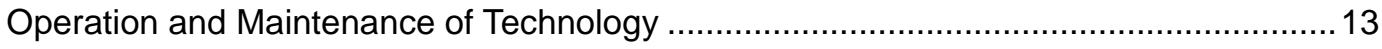

Service/Support Requirements .......................................................................... 13

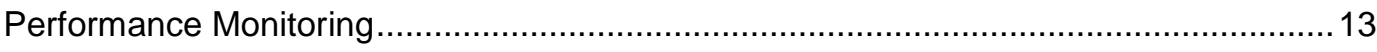

Appendix: FEAP Ad Flyer, “Anti-Scale/Corrosion Resistant Coating”................................. 14

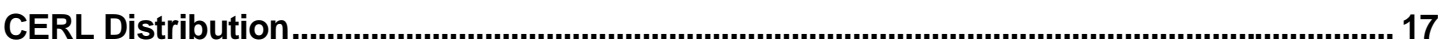

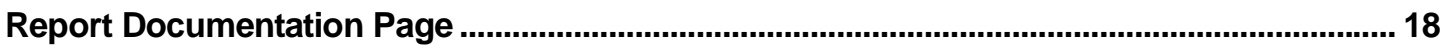





\section{Executive Summary}

Most domestic water storage heaters used in the Army consist of a removable Utube bundle installed in the lower half of a horizontal or vertical cylindrical boiler tank. The copper U-tube bundle used in cement-lined carbon steel tanks requires periodic removal (in locations with high scaling tendencies, as often as every 90 days) and acid cleaning to remove the excessive (0.011-in. thick) scale formation on the water-side surfaces of the tube bundle. Total softening of the water to remove scale is not feasible because it renders the water corrosive to the piping system. To ensure water potability and to protect human health, scale dispersants are prohibited in such systems. To protect the copper tubing in the heat exchanger, a phenolic coating (rated for dry heat temperatures up to 300 ${ }^{\circ} \mathrm{F}$ ) has been adapted for use on tube bundles with a typical operating pressure of about 12-15 psi, exposed to corrosive and scale conducive environments.

\section{Points of Contact}

Mr. Vincent F. Hock

U.S. Army Construction Engineering Research Laboratories (CERL)

ATTN: CECER-FM

PO Box 9005

Champaign, IL 61826-9005

tel.: $217 / 373-6753$

FAX: 217/373-7222

Wisconsin Protective Coating Corp.

PO Box 8147

Green Bay, WI 54308-8147

tel.: 414/437-6561

FAX: 414/437-8083
Directorate of Engineering and Housing (DEH)

ATTN: AFZF-DE-MNT

Bldg. 4218

Fort Hood, TX 76544-5057

tel.: 817/287-4405

FAX: 817/287-8249

Heresite Protective Coatings

822 S. 14th Street

PO Box 250

Manitowoc, WI 54221-0250

tel.: $800 / 558 / 7747$

FAX: 920/684-0110 


\section{Units of Weight and Measure}

U.S. standard units of measure are used throughout this report. A table of conversion factors for Standard International (SI) units is provided below.

$\begin{array}{lll}1 \mathrm{Btu} & = & 100,000 \mathrm{therm}=1055.56 \text { Joule } \\ 1 \mathrm{Btu} /\left(\mathrm{hr}-\mathrm{sq} \mathrm{ft} .{ }^{\circ}{ }^{\circ} \mathrm{F}\right) & = & 5.67826 \mathrm{~W} /(\mathrm{sq} \text { meter- } \mathrm{C}) \\ 1 \mathrm{Btu} /\left(\mathrm{lb}-{ }^{\circ} \mathrm{F}\right) & = & 4186.8 \mathrm{Joule} /(\mathrm{Kg}-\mathrm{C}) \\ 1 \mathrm{gal}(\text { U.S. }) & = & 3.787412 \mathrm{I} \\ 1 \mathrm{gal}(\text { U.S. }) / \mathrm{min} & = & 0.0630902 \mathrm{l} / \mathrm{sec} \\ 1 \mathrm{mil} & = & 0.0000245 \mathrm{~m} \\ 1 \mathrm{in} . & = & 25.4 \mathrm{~mm}=0.0254 \mathrm{~m} \\ 1 \mathrm{lb} & =0.453592 \mathrm{~kg} \\ 1 \mathrm{lb} / \mathrm{in}^{2} \text { (psi) } & = & 6894.76 \mathrm{Pas} \\ 1 \mathrm{lb} / \mathrm{gal} \text { (U.S.) } & =0.1198264 \mathrm{~kg} / \mathrm{l}\end{array}$




\section{Pre-Acquisition}

\section{Description of the Technology}

The U.S. Army Construction Engineering Research Laboratories (CERL) has adapted a baked-on phenolic coating, known as P-403, for use on the water-side of copper U-tube bundles for mitigation of corrosion/scaling induced failures. When the coatings are applied to copper tube heat exchanger bundles, the maximum reduction in heat transfer efficiency is approximately 5 percent over the life of the coatings. This outweighs the 60 percent heat transfer reduction associated with a 0.008 -in. thick scale deposit after 90 days of operation.

The phenolic coating is manufactured by Heresite-Saekaphen of Manitowoc, WI, and has been undergoing preliminary laboratory evaluation and field demonstration at several locations for the past 4 years. The coating is rated for dry heat temperatures up to $300{ }^{\circ} \mathrm{F}$, and can be applied through either a spraying or immersion process. The coating is 60 percent solids by weight and 41 percent solids by volume. The heat exchanger coating consists of four coats of pigment, forming a 0.004- to 0.006-in. (dry film thickness) base coat. Two additional coats of an unpigmented, baked phenolic coating create a 0.002-in. (dry film thickness) top coat. The pigmented base layer of the baked phenolic coating system is currently being used without the unpigmented top coat in carbon steel steam condensate return lines. In addition, the coatings can be applied to both new and previously scaled/corroded tube bundles or pipes.

\section{Life Cycle Cost Analysis}

The coating greatly reduced maintenance and repair costs for installations with corrosion and/or scaling problems associated with heat exchangers. The cost of the coating, including removing and reinstalling the tube bundle (for one bundle) is about $\$ 800$, and the annual cost avoidance is $\$ 5050$ per exchanger under the severe scaling conditions at Fort Hood, TX. Table 1 shows the overall cost savings as projected at a severe scaling site (Fort Hood) and a severe corrosive/erosive site (Fort Lewis, WA). These results can be extended to other Army installations. 
Table 1. Simple payback for coating heat exchangers at Fort Hood and Fort Lewis.

\begin{tabular}{|l|c|c|c|c|}
\hline Site & $\begin{array}{c}\text { No. of } \\
\text { Exchangers }\end{array}$ & $\begin{array}{c}\text { Annual Cost } \\
\text { of Problem }\end{array}$ & $\begin{array}{c}\text { Cost of Coating } \\
\text { All Exchangers }\end{array}$ & Simple Payback \\
\hline Fort Hood & 115 & $\$ 56,923$ & $\$ 92,000$ & 1.6 years \\
\hline Fort Lewis & 97 & $\$ 60,624$ & $\$ 77,600$ & 1.3 years \\
\hline
\end{tabular}




\section{Acquisition/Procurement}

\section{Potential Funding Sources}

Army installations may use the Maintenance and Repair " $\mathrm{K}$ " account funds to procure baked phenolic coating of domestic hot water heat exchangers.

\section{Technology Components and Sources}

Two manufacturers of the phenolic resin coating are:

Heresite Protective Coatings

PO Box 250

Manitowoc, WI 54221-0250

tel.: $800 / 558 / 7747$

FAX: $414 / 684-0110$
Wisconsin Protective Coating Corp.

PO Box 8147

Green bay, WI 54308-8147

tel.: 414/437-6561

FAX: 414/437-8083

It is recommended that the coating be applied and cured by the manufacturer.

\section{Procurement Documents}

The Corps of Engineers Guide Specifications (CEGS) 15400 Plumbing, General Purpose, section 2.10.3 shall be cited for application of the phenolic resin coating system on either old or new domestic hot water heat exchangers. For hospital applications, CEGS 15405, Plumbing, Hospital, section 2.13 .3 shall be cited. These specifications are presented below. 


\section{Corps of Engineers Guide Specification Section 15400 Plumbing, General Purpose}

\subsubsection{Phenolic Resin Coatings}

The phenolic resin coil coating system shall be a product specifically intended for use on steel, copper, copper alloy, and stainless steel water heating coils. All coating components shall be capable of withstanding dry heat temperatures up to 300 degrees F. All coating material shall meet the requirements of CFR 21 Part 175. The coating system shall consist of the following three components:

\subsubsection{Wash Primer}

The wash primer shall be composed of a combination of polyvinyl butyral and a heat hardening phenolic resin. The weight per gallon shall be between $7.0 \mathrm{lbs} /$ gallon minimum and $7.4 \mathrm{lbs} /$ gallon maximum.

\subsubsection{Pigmented Base Coat}

The pigmented baking phenolic base coat shall consist of heat hardening phenolic resins, suitable pigments of the earth type, and softening agents. It shall not contain drying oils or cellulose material. The weight per gallon shall be between $10.3 \mathrm{lbs} /$ gallon minimum and 10.7 lbs/gallon maximum. The non-volatile solids content shall be between 60 percent minimum and 64 percent maximum by weight.

\subsubsection{Clear Top Coat}

The clear non-pigmented baking phenolic top coat shall have a weight per gallon of between $8.65 \mathrm{lbs} /$ gallon minimum and $8.95 \mathrm{lbs} /$ gallon maximum. The non-volatile solids content shall be between 48 percent minimum and 52 percent maximum by weight. 


\section{Corps of Engineers Guide Specification Section 15405 Plumbing, Hospital}

\subsubsection{Phenolic Resin Coating}

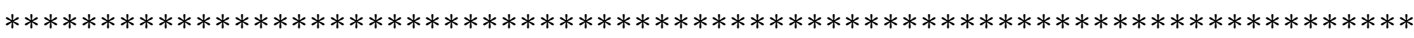

NOTE: If interior erosion of the tubes at or near the tube sheet is expected to be a severe problem, change the wording of this paragraph and its subparagraphs to require the coating to be applied to the first 5 to 8 inches inside the tubes by brushing.

The phenolic resin coating shall be applied at either the coil or coating manufacturer's factory. The coil shall be chemically cleaned to remove any scale if present and to etch the metal surface. The exposed exterior surface of the coil shall be abrasively cleaned to white metal blast in accordance with SSPC SP 5 . The coating shall be a product specifically intended for use on the material the water heating coils are made of (i.e., steel, copper, copper alloy, or stainless steel). All coating components shall be capable of withstanding temperatures up to 300 degrees F dry bulb; and meet the requirements of CFR 21 Part 175. [The entire exterior surface] [and] [the first 5 to 8 inches inside the tubes] of each coil shall be coated with the three component phenolic resin coating system. The system shall consist of the following: the wash primer, the pigmented base coat, and the clear top coat. Immediate and final cure times and temperatures shall be as recommended by the coating manufacturer.

\subsubsection{Coating Coil Interiors}

One coat of the wash primer component shall be applied by brushing or flooding. Several coats of the pigmented base component shall be applied be brushing, immersion, or flooding. Several coats of the clear top (non-pigmented) component shall be applied by brushing, immersion, or flooding, with exception of the final coat which may be applied by spraying. 


\subsubsection{Coating Coil Exteriors}

One coat of the wash primer component shall be applied by flooding. Several coats of the pigmented base component shall be applied by immersion or flooding. Several coats of the clear top (non-pigmented) component shall be applied be immersion or flooding, with exception of the final coat which may be applied by spraying.

\subsubsection{Coating Components}

a. Wash Primer. The wash primer component shall be composed of a combination of a polyvinyl butyral and heat hardening phenolic resin. The weight per gallon shall be between $7.0 \mathrm{lbs} /$ gallon minimum and $7.4 \mathrm{lbs} /$ gallon maximum.

b. Pigmented Base. The pigmented base component shall be applied to dry film thickness of 0.004 to 0.006 in. The pigmented base shall consist of heat-hardening phenolic resins, suitable pigments of the earth type, and softening agents. It shall not contain drying oils or cellulose material. The weight per gallon shall be between 10.3 lbs/gallon minimum and $10.7 \mathrm{lbs} /$ gallon maximum. The non-volatile solids content shall be between 60 percent minimum and 64 percent maximum by weight.

c. Clear Top. The clear top (non-pigmented) component shall be applied until the dry film thickness of the total coating system is between 0.005 and 0.007 inch. The clear non-pigmented top coat shall have a weight per gallon of between $8.65 \mathrm{lbs} /$ gallon minimum and 8.95 lbs/gallon maximum. The non-volatile solids content shall be between 48 percent minimum and 52 percent maximum by weight.

For background information on the development of the baked phenolic coating, see CERL Technical Report (TR) M-91/05/ADA231716, Development and Testing of an Anti-Scale/Corrosion Resistant Coating for Domestic Hot Water Heat Exchangers (CERL December 1990).

\section{Procurement Scheduling}

The lead time for having a heat exchanger bundle factory coated and cured is approximately 3 to 4 weeks, exclusive of shipping time. Multiple tube bundles can be coated simultaneously. 


\section{Post-Acquisition}

\section{Initial Implementation}

Installation of factory-coated heat exchangers requires no specialized labor; these systems can be installed easily by in-house labor. Care must be taken however to ensure personnel safety any time high temperature hot water or steam lines are the subject of invasive work (i.e., opened or disconnected).

\section{Operation and Maintenance of Technology}

The operation and maintenance of the factory-coated heat exchanger bundle does not differ from the uncoated tube bundle. The amount of time between periodic inspections for scale or corrosion can be extended to 6 months.

\section{Service/Support Requirements}

The manufacturer and applicator of the phenolic coating can assist with the requirements of coated heat exchanger technology.

\section{Performance Monitoring}

Removing and inspecting coated heat exchangers is no different from the case of uncoated heat exchangers. It is anticipated that recoating of these systems will be required every 5 years based on site-specific water chemistry, shell-and-tube geometry, and operating parameters. 


\section{Appendix: FEAP Ad Flyer, "Anti-Scale/Corrosion Resistant Coating"}




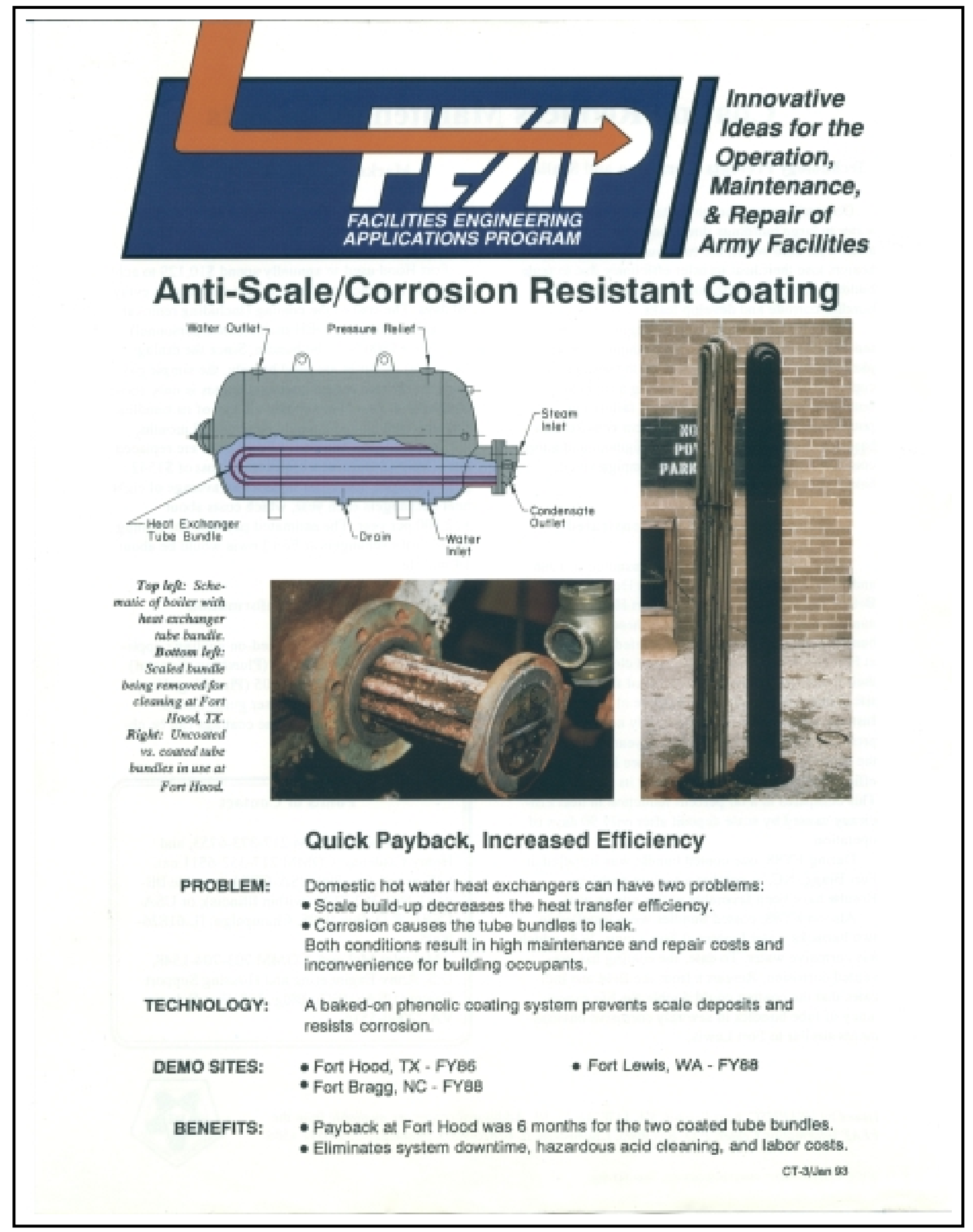




\section{Coating Reduces Maintenance Costs}

\section{Technology Prevents Corrosion and Scaling}

Domestic water storage heaters supply potable hot water to large buildings throughout the Army. In areas with hard water, the tube bundles in these heaters lose their heat transfer efficiency due to scale buildup. In regions with corrosive water, the tube bundles corrode and develop leaks. The U.S. Army Construction Engineering Research Laboratory (CERL) adapted a baked-on phenolic coating system for use on the water side of copper U-tube bundles. This coating system stops both scaling and corrosion-induced failures in potable hot water heaters. The system consists of a base coat formed by four coats of pigment and a top coat composed of two coats of an unpigmented, baked phenolic coating.

\section{Coatings Benefits Demonstrated}

Two coated tube bundles were installed in 1986 and 1987 in dining facilities at Fort Hood, TX. Before the coating was applied, Fort Hood maintenance personnel had to acid clean these scaled bundles every 90 days. The two coated tube bundles at Fort Hood have not required acid cleaning since their installation. This has eliminated the need for site personnel to handle and dispose of the chemicals. Instead, the coated coils have simply needed a high- pressure water rinse about every 2 years. In addition, the coating is expected to only reduce heat transfer efficiency by about 10 percent over its service life. This compares to a 60 percent reduction in heat efficiency caused by scale deposit after only 90 days of operation.

During FY88, one coated bundle was installed at Fort Bragg, NC, to combat a scaling problem. Results have been favorable at this site as well. Also in FY88, coated bundles were installed in two barracks water heaters at Fort Lewis, WA, which has corrosive water. To date, the coating has prevented corrosion. Research from the field test indicates that the coating could double the life expectancy of tube bundles in severely corrosive environments similar to Fort Lewis.

\section{Market Analyses Show Savings}

Market analyses were conducted at Forts Hood and Lewis to determine the cost savings for both scaling and corrosion sites. Fort Hood used to annually spend $\$ 10,129$ to acid clean the two uncoated, scaled heat exchangers every 90 days. The cost of the coating (including removal and reinstallation by DEH maintenance personnel) was about $\$ 800$ per tube bundle. Since the dining hail water facilities are used heavily, the simple payback for the two coated heat exchangers is only about 6 months. If Fort Hood coated all 115 of its bundles, the projected payback would be about 18 months. Corroded tube bundles at Fort Lewis are replaced about every 5 years at a high capital cost of $\$ 1542$ per exchanger. The DEH replaces an average of eight heat exchangers each year, which costs about $\$ 12,300$ per year. The estimated payback for coating all 97 heat exchangers at Fort Lewis would be about 14 months.

\section{Procurement Information}

For information on the baked-on coating's applications, refer to CEGS 15400 (Plumbing, General) section 2.10.4 and CEGS 15405 (Plumbing, Hospital) section 2.13.3. A FEAP user guide also is available from CERL. The coatings can be obtained from several vendors.

\section{Points of Contact}

Vince Hock, COMM 217-373-6753, or tollfree 800-USA-CERL (outside Illinois), 800252-7122 (within Illinois); or USA-CERL, P.O. Box 9005, Champaign, IL 61826-9005.

Joe McCarty, COMM 703-428-7266, Headquarters, U.S. Army Corps of Engineers (HQUSACE), ATTN: CECW-ET, 441 G St., NW., Washington, DC 20314-1000.

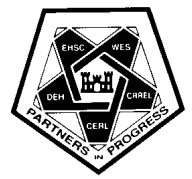




\section{CERL Distribution}

HQUSACE

ATTN: CEMP-RI (2)

Chief of Engineers

ATTN: CEHEC-IM-LH (2)

ATTN: HECSA Mailroom (2)

ATTN: CECC-R

Engineer Research and Development Center (Libraries)

ATTN: ERDC, Vicksburg, MS

ATTN: Cold Regions Research, Hanover, NH

ATTN: Topographic Engineering Center, Alexandria, VA

Defense Tech Info Center 22304

ATTN: DTIC-O 


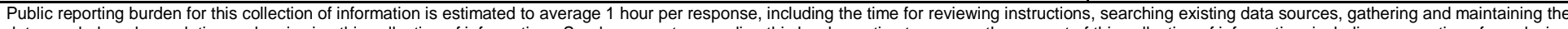

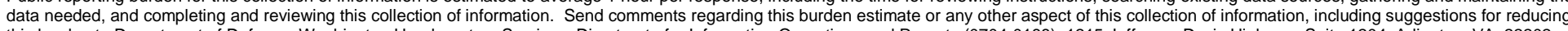

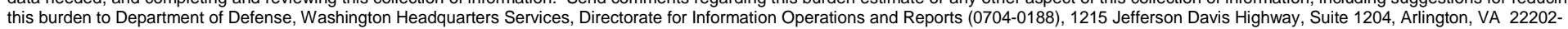

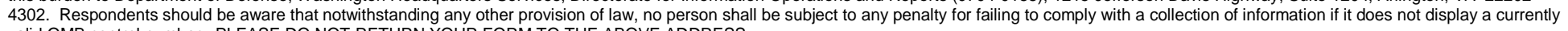
valid OMB control number. PLEASE DO NOT RETURN YOUR FORM TO THE ABOVE ADDRESS.
1. REPORT DATE (DD-MM-YYYY)
2. REPORT TYPE
3. DATES COVERED (From - To)

$01-2001$

Final

4. TITLE AND SUBTITLE

User Guide and Specifications for Baked Phenolic Coating Systems Applied to Domestic Hot

Water Heat Exchangers

5a. CONTRACT NUMBER

5b. GRANT NUMBER

5c. PROGRAM ELEMENT NUMBER

6. AUTHOR(S)

Vincent F. Hock

5d. PROJECT NUMBER

FEAP

5e. TASK NUMBER

M3

5f. WORK UNIT NUMBER

K92

\section{PERFORMING ORGANIZATION NAME(S) AND ADDRESS(ES)}

U.S. Army Engineer Research and Development Center (ERDC)

Construction Engineering Research Laboratory (CERL) P.O. Box 9005

Champaign, IL 61826-9005

\section{SPONSORING / MONITORING AGENCY NAME(S) AND ADDRESS(ES)}

Headquarters, U.S. Army Corps of Engineers (HQUSACE)

441 G Street, NW.

Washington, DC 20314-1000 11. SPONSOR/M
NUMBER(S)

8. PERFORMING ORGANIZATION REPORT

NUMBER

ERDC/CERL SR-01-1

10. SPONSOR/MONITOR'S ACRONYM(S)

CEMP-RI

1. SPONSOR/MONITOR'S REPORT

\section{DISTRIBUTION / AVAILABILITY STATEMENT}

Approved for public release; distribution is unlimited.

\section{SUPPLEMENTARY NOTES}

Copies are available from the National Technical Information Service, 5285 Port Royal Road, Springfield, VA 22161.

\section{ABSTRACT}

Most domestic water storage heaters used in the Army consist of a removable U-tube bundle installed in the lower half of a horizontal or vertical cylindrical boiler tank. The copper U-tube bundle used in cement-lined carbon steel tanks requires periodic removal and acid cleaning to remove the excessive scale formation on the water-side surfaces of the tube bundle. Total softening of the water to remove scale is not feasible because it renders the water corrosive to the piping system. To ensure water potability and to protect human health, scale dispersants are prohibited in such systems. This study adapted a phenolic coating for use on tube bundles exposed to corrosive and scale conducive environments to protect the copper tubing in the heat exchanger.

\section{SUBJECT TERMS}

coatings

heat exchangers

16. SECURITY CLASSIFICATION OF:
\begin{tabular}{|l|l|l|}
\hline $\begin{array}{c}\text { a. REPORT } \\
\text { Unclassified }\end{array}$ & $\begin{array}{c}\text { b. ABSTRACT } \\
\text { Unclassified }\end{array}$ & $\begin{array}{c}\text { c. THIS PAGE } \\
\text { Unclassified }\end{array}$ \\
\hline
\end{tabular}

user manuals

\begin{tabular}{|c|c|c|}
\hline $\begin{array}{c}\text { 17. LIMITATION } \\
\text { OF ABSTRACT }\end{array}$ & $\begin{array}{c}\text { 18. NUMBER } \\
\text { OF PAGES }\end{array}$ & $\begin{array}{c}\text { 19a. NAME OF RESPONSIBLE PERSON } \\
\text { Vincent F. Hock }\end{array}$ \\
\cline { 3 - 3 } SAR & 20 & $\begin{array}{c}\text { 19b. TELEPHONE NUMBER (in- } \\
\text { clude area code) } \\
\text { (217) } 373-6753\end{array}$ \\
\hline
\end{tabular}

Standard Form 298 (Rev. 8-98) Prescribed by ANSI Std. 239.18 